\title{
Investigation of Sodium Benzoate and Potassium Sorbate Content and Evaluation of Microbiological Parameters of Fresh Kashar Cheeses
}

\author{
Osman Gul ${ }^{1}$ and Muhammet Dervisoglu* \\ Department of Food Engineering, Ondokuz Mayis University, Samsun 55139, Turkey \\ ${ }^{1}$ Program of Food Technology, Yeşilyurt Demir Çelik Vocational School, Ondokuz Mayis University, Samsun 55330, Turkey
}

\begin{abstract}
Food safety is important issue for consumers and recently the usage of food ingredients especially food preservatives are limited by regulations. However, some manufacturers use food preservatives instead of improving their hygienic production. Therefore, the levels of sodium benzoate and potassium sorbate of 147 vacuum packaged Kashar (fresh) cheese samples produced in Black Sea Region, Turkey were investigated and some microbiological properties were determined. Research results demonstrated that the production of vacuumed Kashar cheese in Black Sea Region was not standardized for all production periods depending on the microbiological properties. Coliform and E. coli counts detected in the cheese samples showed that necessary hygienic conditions were not provided for Kashar cheese production. Staphylococcus aureus was not determined in the cheese samples. The sodium benzoate and potassium sorbate were analyzed by HPLC-DAD. Potassium sorbate levels $(69.39 \mathrm{mg} / \mathrm{kg})$ of Kashar cheese samples were determined to be lower than the maximum permitted concentration of Turkish Food Codex. Although the utilization of sodium benzoate is prohibited by the Codex, the average level of sodium benzoate of cheese samples was detected to be $68.63 \mathrm{mg} / \mathrm{kg}$. Sodium benzoate can be naturally occurred in fresh cheese at concentrations of up to $50 \mathrm{mg} / \mathrm{kg}$.
\end{abstract}

Key words: food safety, Kashar cheese, potassium sorbate, sodium benzoate

\section{Introduction}

Food additives are generally added to processed foods for prolong the shelf-life by protecting them from deterioration caused by microorganisms (Mpountoukas et al., 2008). For this purpose widely used chemical preservatives are benzoic and sorbic acids and their salts (sodium benzoate and potassium sorbate) (Tfouni and Toledo, 2002). These compounds show their effect in acidic conditions $(\mathrm{pH} 4.5)$ as preservatives. They are generally used to inhibit mold and yeast growth and also effective against many bacteria (Can et al., 2011). Sodium benzoate which is the sodium salt of benzoic acid is preferred compared to benzoic acid since its solubility in water is higher than that of benzoic acid (Pylypiw and Grether, 2000). Although sodium benzoate is known as generally recognized as safe (GRAS), some adverse effects, such as asthma, urticaria, metabolic acidosis and convulsions, have been observed

\footnotetext{
*Corresponding author: Muhammet Dervisoglu, Department of Food Engineering, Ondokuz Mayis University, Samsun 55139, Turkey. Tel: 90-362-312-1919/1510, Fax: 90-362-457-6035, Email: mderviso@omu.edu.tr
}

at low doses in sensitive persons (Gi et al., 2009). The Joint FAO/WHO Expert Committee on Food Additives (JECFA) established an Acceptable Daily Intake (ADI) of sodium benzoate to be $0-5 \mathrm{mg} / \mathrm{kg}$ of the body weight (WHO, 1996). Potassium sorbate is the potassium salt of sorbic acid and it is more soluble in water than sorbic acid (Deeb and Ahmed, 2010). Sorbic acid and its salts have less harmful effect than benzoic acid and its salts since they are metabolized rapidly like some fatty acids (as butyric, caproic acid) in human and animals (Koyuncu and Uylaser, 2009). The ADI value of sorbic acid and its salts is $0-25 \mathrm{mg} / \mathrm{kg}$ body weight as established by the JECFA (WHO, 1974). Through limits of food additives in foodstuff are important for consumer health, their usage have been established by regulatory authorities in different countries. Therefore, sodium benzoate and potassium sorbate have also limitations of usage to protect human health (Can et al., 2011). According to Turkish Food Codex maximum legally allowable limit for potassium sorbate in cheese is set at $1,000 \mathrm{mg} / \mathrm{kg}$ and the usage of sodium benzoate in dairy products is prohibited. However, the sodium benzoate is available as a maximum $5 \mathrm{mg} / \mathrm{kg}$ in cheese produce with rennet (Anon, 2013). 
Kashar is a semi-hard Turkish traditional cheese which is the second popular one among cheeses in Turkey, after White cheese (Koca and Metin, 2004). This cheese shows some similarities with other kinds of cheeses, such as Kashkaval in Bulgaria, Kasseri in Greece, and Caciocavallo and Ragusona in Italy (Guler, 2005). It is classified as "fresh Kashar cheese" and "ripened Kashar cheese" depending on the ripening by the Turkish Standards (TS3272). Ripened Kashar cheese is ripened at least $90 \mathrm{~d}$ to improve characteristic properties while fresh cheese is produced from pasteurized milk without a ripening process and sold as fresh (Anon, 2006). Ripened Kashar cheese has a hard texture, but the texture of fresh Kashar cheese is semi hard (Hayaloglu, 2009).

Although there have been many studies related to microbiological quality of Kashar cheese (Gulmez et al., 2004; Gunsen and Buyukyoruk, 2003; Oksuztepe et al., 2009), number of the studies highlighting the quality of Kashar cheese produced in Black Sea Region which takes place in north of Turkey is limited. The aim of the present study was to determine the content of sodium benzoate and potassium sorbate and some microbiological characteristics of vacuum packaged Kashar cheeses manufactured at October-November, February-March and May-June time periods in the Black Sea Region of Turkey.

\section{Materials and Methods}

\section{Materials}

Kashar cheese is produced using raw ewe or cows' milk or their mixture and fermentation is performed with the native microflora of milk (lactic acid bacteria). The traditional method involves renneting, curd forming, curd fermentation (about pH 5.1-5.4), scalding and texturing of curd in hot water $\left(65-80^{\circ} \mathrm{C}\right)$ containing $6-8 \% \mathrm{NaCl}$, shaping of the scalded curd, pre-ripening at $15-20^{\circ} \mathrm{C}$ and ripening at $2-4^{\circ} \mathrm{C}$ for at least 3 mon (Hayaloglu, 2009). Maturated Kashar cheese is produced in dimensions of 27$30 \mathrm{~cm}$ diameter and 10-13 height and 6-10 kg weight. It is maturated before packaging at $2-3^{\circ} \mathrm{C}$ for $3-10$ mon (Cetinkaya et al., 2003). Therefore, the cheese is gained its characteristic flavor after storage period (Hayaloglu, 2009).

In our study, a total of 147 vacuum packaged Kashar cheese samples produced by different 49 plants in the period of October-November 2007 (49 cheese samples), February-March 2008 (49 cheese samples) and May-June 2008 (49 cheese samples) were purchased randomly from shops in (the city of Amasya, Bartin, Bayburt, Bolu, Çorum, Düzce, Giresun, Gümüşhane, Karabük, Kastamonu, Ordu,
Samsun, Sinop, Tokat, Trabzon and Zonguldak) Black Sea Region of Turkey. Cheese samples (0.5-1 kg) were kept in insulated containers at $4 \pm 1^{\circ} \mathrm{C}$ until analysis.

\section{Microbiological analysis}

Cheese samples $(10 \mathrm{~g})$ were homogenized in $90 \mathrm{~mL}$ of a $0.85 \%(\mathrm{w} / \mathrm{v})$ sterile $\mathrm{NaCl}$ solution using a stomacher Lab-Blender (Smasher, AES Chemunex, France). Decimals dilutions ranged from $10^{-1}$ to $10^{-6}$ were prepared and petri plated on specific media. The following media and incubation conditions were used to enumerate microbial counts of samples: Baird Parker agar (incorporating 5\% Egg Yolk Tellurite Emulsion) for Staphylococcus aureus at $37^{\circ} \mathrm{C}$ for $24 \mathrm{~h}$ (Anon, 2001), Violet-Red Bile agar for coliform bacteria at $37^{\circ} \mathrm{C}$ for $24 \mathrm{~h}$ (Mc Brearty et al., 2001), Chromocult TBX Agar for Escherichia coli at $44^{\circ} \mathrm{C}$ for $24 \mathrm{~h}$ (Anon, 1999) and Wort agar for yeasts and molds at $30^{\circ} \mathrm{C}$ for $72 \mathrm{~h}$ (Gobbetti et al., 1999).

\section{Analysis of sodium benzoate and potassium sor- bate}

\section{Reagents and standards}

Acetonitrile (Lichrosol), glacial acetic acid and ammonium acetate were purchased from Merck (Germany) and commercial standards of sodium benzoate and potassium sorbate were obtained from Supelco (USA). Ultra pure water used for chromatography processing was produced using Millipore Direct-Q UV system from Millipore SAS (France).

\section{Sample preparation}

The liquid chromatography technique was used to determine the concentrations of sodium benzoate and potassium sorbate in the samples by following the procedures described by Pylypiw and Grether (2000). Briefly, $10 \mathrm{~g}$ of homogenized cheese sample was thoroughly mixed with $50 \mathrm{~mL}$ of mobile phase and blended for $2 \mathrm{~min}$. The sample blend was then allowed to settle for $5 \mathrm{~min}$ and $1 \mathrm{~mL}$ of the supernatant liquid was diluted 1:10 with mobile phase. After dilution, all samples were filtered through a $25 \mathrm{~mm} \times 0.45 \mu \mathrm{m}$ nylon Acrodisk filter to remove particulate matter from the samples. The filtrate was used in the analysis that was done duplicate.

\section{Chromatographic conditions}

Sodium benzoate and potassium sorbate analysis were carried out using HPLC system (Shimadzu, Japan) equipped with a pump (Shimadzu LC-20AT, Japan), photo- 
diode array detector (Shimadzu SPD-M20A, Japan), column oven (Shimadzu CTO-10AS VP, Japan) set $20^{\circ} \mathrm{C}$, auto sampler (Shimadzu SIL-10A, Japan) and data station (Shimadzu LC-20AT, Japan). The chromatography column was a Supelcosil LC-18, $5 \mu \mathrm{m}, 250 \mathrm{~mm} \times 4.6 \mathrm{~mm}$ (Supelco, USA). The mobile phase was 90:10, acetate buffer ( $\mathrm{pH} 4.2)$ and acetonitrile. The analysis was carried out isocratically at a flow rate of $0.8 \mathrm{~mL} / \mathrm{min}$. Injection volume was assayed as $10 \mu \mathrm{L}$. The detection of sodium benzoate and potassium sorbate was carried out at the wavelengths of maximum absorption of the compounds to be 225 and $255 \mathrm{~nm}$, respectively.

\section{Preparation of standard curves}

Firstly, sodium benzoate and potassium sorbate stock solutions (buffer stock) were prepared in HPLC-grade water at $500 \mathrm{mg} / \mathrm{L}$ concentration. Then, final concentrations $(1,5,10,20$ and $50 \mathrm{mg} / \mathrm{L})$ for calibration curve were injected into mobile phase from buffer stock. The solutions were found to be stable at least $30 \mathrm{~d}$ when they kept at room temperature.

\section{Statistical analyses}

Statistical analysis was performed using SPSS version 17.0 (SPSS Inc. USA). ANOVA was used to determine the effect of region and period on preservative content and quality parameters and Duncan test was applied for multiple comparison $(p=0.05)$.

\section{Results and Discussion}

\section{Microbiological characteristics}

The microbiological analysis of vacuumed Kashar cheese samples were given in Table 1 . The mean yeast and mold counts of the samples was found to be $6.5 \mathrm{Log} \mathrm{CFU} / \mathrm{g}$. This was higher than those found by Oksuztepe et al. (2009) and Gunsen and Buyukyoruk (2003). Yeasts and molds which may result from different sources contaminate the product during production (Var et al., 2006). Yeast and molds growth on dairy products is one of the most important problems. Through the post process contamination during handling and packaging of the product, the quality and shelf-life of cheese is affected negatively (Ture et al., 2011). Especially, when yeast and mold counts reached 7$8 \mathrm{Log} \mathrm{CFU} / \mathrm{g}$, they cause organoleptic change by hydrolyzing fats (Var et al., 2006).

Presence of coliform bacteria and E. coli was detected in $21(14.29 \%)$ and $11(4.48 \%)$ of cheese samples, respectively. Oksuztepe et al. (2009) found that all vacuum cheese samples produced in Elazig were contaminated with coliform the mean of $1.71 \mathrm{Log} \mathrm{CFU} / \mathrm{g}$ and were contaminated with $E$. coli ( $8 \%$ of total samples) the mean of 1.3 Log CFU/g. The coliform bacteria are fecal origin and their presence in cheese indicates the evidence of poor manufacturing conditions and lack of hygiene (Hayaloglu and Kirbag, 2007). E. coli species is often used as indicator microorganism of which presence implies a risk that other enteric pathogens may be also present (Chye, 2004). The presence of E. coli in the cheese may be due to use of raw milk and/or contamination of the product during manufacture of the product.

$S$. aureus was not detected in any samples. Oksuztepe et al. (2009) and Gulmez et al. (2004) also reported similar results in cheeses. On contrary to these studies, $S$. aureus was found in $4(8 \%)$ of total vacuum cheese samples by Gunsen and Buyukyoruk (2003). Normally, this pathogen may be present in cheese at first stage of maturation, and then it becomes inactivated as ripening proceeds (Hayaloglu and Kirbag, 2007). But, fresh Kashar cheese is produced from pasteurized milk, without a ripening process and sold as fresh. Therefore, the presence of this pathogen suggests that environmental conditions were not controlled during manufacturing or inadequately pasteurized milk was used in the cheese production.

Levels of sodium benzoate and potassium sorbate

The standard curves were obtained from sodium benzoate and potassium sorbate concentration between 1-50

Table 1. Microbiological counts (Log CFU/g) of vacuumed Kashar cheese obtained from Black Sea region*

\begin{tabular}{|c|c|c|c|c|c|c|}
\hline \multirow{2}{*}{ Period } & \multicolumn{2}{|c|}{ Yeasts and Molds } & \multicolumn{2}{|c|}{ Coliform } & \multicolumn{2}{|c|}{ E. coli } \\
\hline & Mean & Min-Max & Mean & Min-Max & Mean & Min-Max \\
\hline October-November & $6.17^{\mathrm{a}}$ & $4.57-7.34$ & $1.31^{\mathrm{a}}$ & $<0.01-1.9$ & $1.43^{\mathrm{a}}$ & $<0.01-1.9$ \\
\hline February-March & $6.68^{b}$ & $4.76-8.01$ & $1.79^{\mathrm{a}}$ & $<0.01-3.45$ & $1.11^{\mathrm{a}}$ & $<0.01-2.08$ \\
\hline May-June & $6.58^{b}$ & $4.48-7.97$ & $2.76^{\mathrm{b}}$ & $2.18-3.29$ & $2.4^{\mathrm{b}}$ & $1.95-2.69$ \\
\hline Overall Average & 6.5 & $4.48-8.01$ & 1.77 & $<0.01-3.45$ & 1.65 & $<0.01-2.69$ \\
\hline
\end{tabular}

* $S$. aureus was not detected in any sample.

1a-b: Means with different letters in a row within the category are significantly different $(p<0.05)$.

Means were calculated with samples where the Coliform and $E$. coli were detected. 
$\mathrm{mg} / \mathrm{L}\left(\mathrm{r}^{2}=0.9993\right.$ and 0.9998 , respectively). The detection limit, calculated as the concentration corresponding to the background noise, was $0.2 \mathrm{mg} / \mathrm{kg}$ for both preservatives. For mean recoveries, 5,20 and $50 \mathrm{mg} / \mathrm{L}$ of both preservatives were added to cheese and afterwards the levels of both preservatives were measured in these samples. The mean recoveries were calculated to be $92.8 \%$ and 96.7 for sodium benzoate and potassium sorbate, respectively.

Table 2 shows mean concentrations of sodium benzoate and potassium sorbate in vacuumed Kashar cheese samples. From 147 samples analyzed, sodium benzoate and potassium sorbate were detected in $83(56.46 \%)$ and 14 (9.52\%) samples, respectively. Mean concentrations of sodium benzoate and potassium sorbate in cheese samples were 68.63 and $69.39 \mathrm{mg} / \mathrm{kg}$ and at the levels ranged between $25.46-310.84$ and $22.47-191.64 \mathrm{mg} / \mathrm{kg}$. Only 6 $(4.08 \%)$ cheese samples contained both of sodium benzoate and potassium sorbate. The potassium sorbate levels of Kashar cheese samples were determined lower than the maximum permitted concentration by Turkish Food Codex. Although, the usage of sodium benzoate in cheese is prohibited by the Codex, cheese produce with rennet must contain maximum of $5 \mathrm{mg} / \mathrm{kg}$ sodium benzoate (Anon, 2013). Additionally, benzoic acid is naturally produced from hippuric acid in fermented dairy products at concentrations of up to $50 \mathrm{mg} / \mathrm{kg}$. It is also present in fresh cheese and its concentration is normally below 50 $\mathrm{mg} / \mathrm{kg}$ (Sieber et al., 1995). Fresh Kashar cheese is produced from pasteurized milk without a ripening process and sold as fresh, and there is no information about the occurrence of sodium benzoate in the cheese. Therefore, it is unknown that the sodium benzoate levels detected in cheese samples which was added or occurred naturally. On the other hand, if these additives are used in cheese, they must be declared on the label (Anon, 2006). On the labels of cheese samples produced in Black Sea Region were not stated any information about these additives.
Kucukcetin et al. (2008) examined sodium benzoate and potassium sorbate levels of 20 Kashar and 20 Tulum cheese samples collected from Antalya, and reported that Kashar and Tulum cheese samples contained the means of 280.4 and $187.5 \mathrm{mg} / \mathrm{kg}$ sodium benzoate and 49.7 and $45.6 \mathrm{mg} / \mathrm{kg}$ potassium sorbate, respectively. In another study, Kucukcetin et al. (2004) reported that sodium benzoate levels were between $42.4-441.9 \mathrm{mg} / \mathrm{kg}$ in 7 of 15 white pickled cheese samples and only one of 15 samples contained potassium sorbate $(946.5 \mathrm{mg} / \mathrm{kg})$. Tfouni and Toledo (2002) found that cheese samples contained sorbic acid in the range of $376-1,371 \mathrm{mg} / \mathrm{kg}$. The minimum concentrations of benzoic and sorbic acids required to inhibit microbial growth may vary due to species, $\mathrm{pH}$ of the substrate and other factors (El-Ziney, 2009). Most yeasts and molds are inhibited by $0.001-0.1 \%$ sorbic acid and by $0.002-0.07 \%$ benzoic acid (Gi et al., 2009). According to the results of the present study, the uses of both preservatives were the range of antimicrobial activity.

The highest mean concentrations of sodium benzoate and potassium sorbate were determined in cheese samples produced in May-June, respectively (Table 2). Correlation statistical analysis showed that sodium benzoate was affected to inhibition of yeast and mold counts in fresh Kashar cheese samples collected in May-June $\left(\mathrm{R}_{\mathrm{so}-}\right.$ dium benzoate/yeast and molds $=-0.574 ; p<0.01$ ).

\section{Conclusions}

Our findings demonstrated that there was no hygienic production of vacuumed Kashar cheese in Black Sea Region for all periods. These problems could probably be due to type of milk, manufacturing techniques, storage and marketing conditions, and poor hygienic conditions during manufacturing, storage and marketing. To improve the microbiological quality of cheese, milk should be adequately pasteurized and the processing and storage should be carried out under good hygienic conditions.

Table 2. Sodium benzoate and potassium sorbate contents $(\mathrm{mg} / \mathrm{kg})$ of vacuum Kashar cheese samples obtained from Black Sea region

\begin{tabular}{|c|c|c|c|c|c|c|c|}
\hline \multirow{2}{*}{ Period } & \multirow{2}{*}{$\mathrm{N}$} & \multicolumn{3}{|c|}{ Sodium benzoate } & \multicolumn{3}{|c|}{ Potassium sorbate } \\
\hline & & $\mathrm{n}$ & Mean & Min-Max & $\mathrm{n}$ & Mean & Min-Max \\
\hline October-November & 49 & 34 & $61.76^{\mathrm{a}}$ & $37.34-247.69$ & 4 & $66.45^{\mathrm{a}}$ & $25.34-176.02$ \\
\hline February-March & 49 & 18 & $68.82^{\mathrm{a}}$ & $25.46-168.32$ & 5 & $56.35^{\mathrm{a}}$ & $22.47-144.93$ \\
\hline May-June & 49 & 31 & $74.81^{\mathrm{a}}$ & $39.50-310.84$ & 5 & $84.79^{b}$ & $29.09-191.64$ \\
\hline Overall Average & 147 & 83 & 68.63 & $25.46-310.84$ & 14 & 69.39 & $22.47-191.64$ \\
\hline
\end{tabular}

$\mathrm{N}=$ Number of the samples analyzed, $\mathrm{n}=$ Number of the samples detected.

Means were calculated with samples where the preservatives were detected.

$\mathrm{a}-\mathrm{b}$ : Means with different letters in a column within the category are significantly different $(p<0.05)$. 
The research results about preservatives showed that the levels of potassium sorbate in cheeses were mostly lower than the legal limitations. However, although the usage of sodium benzoate in cheese is prohibited by the legislations, it is being used by most dairy manufacturers in Black Sea Region. Addition to, on the labels of cheese samples were not stated any information about the including these additives. Overall, those problems are mostly resulted from the lack of knowledge of cheese manufacturers about Turkish Food Codex. It may also concluded that new training and monitoring programs are necessary for most dairy producers and the certain legislations should be revised.

\section{Acknowledgements}

This study was financially supported by Ondokuz Mayis University Research Foundation (PYO.MUH.1901.003).

\section{References}

1. Anon. (1999) International Standard ISO 16649-2: Microbiology of food and animal feeding stuffs Horizontal method for the enumeration of presumptive Escherichia coli; Part 2: Colony-count technique at $44^{\circ} \mathrm{C}$ using 5-bromo-4-chloro-3indolyl- $\beta$-D-glucoronic acid.

2. Anon. (2001) Gida ve hayvan yemlerinin mikrobiyolojisiKoagulaz-pozitif stafilakoklarin (Staphylococcus aureus ve dı̆ger türler) sayimi için yatay metot-Bölüm 1: Baird-Parker Agar besiyeri kullanılarak, Türk Standartları Enstitüsü, Ankara, TS 6582-1 EN ISO 6888-1, 1-14 (in Turkish).

3. Anon. (2006) Kashar Cheese Standard, TS 3272. The Institute of Turkish Standards, Ankara, 1-13 (in Turkish).

4. Anon. (2013) Türk gida katki maddeleri yönetmelĭgi. Resmi Gazete, 30.06.2013. Sayi: 28693. Bapbakanlik Basimevi, Ankara (in Turkish).

5. Can, N. O., Arli, G., and Lafci, Y. (2011) A novel RP-HPLC method for simultaneous determination of potassium sorbate and sodium benzoate in soft drinks using C18-bonded monolithic silica column. J. Sep. Sci. 34, 1-9.

6. Cetinkaya, A., Yaman, H., Elmali, M., and Karadagoglu, G. (2003) A preliminary study of Kashar cheese and its organoleptic qualities matured in bee wax. Int. J. Food Safety 6, 1-4.

7. Chye, F. Y., Abdullah, A., and Ayob, M. K. (2004) Bacteriological quality and safety of raw milk in Malaysia. Food Microbiol. 21, 535-541.

8. Deeb, A. M. M. and Ahmed, H. F. (2010) Effect of potassium sorbate and/or probiotic bacteria on spoilage bacteria during cold storage of soft cheese. Global Veterinaria 4, 483-488.

9. El-ziney, M. (2009) GC-MS Analysis of benzoate and sorbate in Saudi dairy and food products with estimation of daily exposure. J. Food Tech. 7, 127-134.

10. Gi, P., Hong, H., Liang, X., and Liu, D. (2009) Assessment of benzoic acid levels in milk in China. Food Cont. 20, 414-418.
11. Gobbetti, M., Folkertsma, B., Fox, P. F., Corsetti, A., Smacchi, E., Angelis, M. D., Rossi, J., Kilcawley, K., and Cortini, M. (1999) Microbiology and biochemistry of Fossa (pit) cheese. Int. Dairy J. 9, 763-773.

12. Guler, Z. (2005) Quantification of free fatty acids and flavor characteristics of Kaşar cheeses. J. Food Lipids 12, 209-221.

13. Gulmez, M., Oral, N., Guven, A., Baz, E., Sezer, C., and Duman, B. (2004) Some Microbiological and chemical properties of Kaşar cheese marketed in Kars-Turkey. J. Fac. Vet. Med. Kafkas Univ. 10, 183-188.

14. Gunsen, U. and Buyukyoruk, I. (2003) Determination of bacteriological qualities and aflatoxin M1 levels of commercially available fresh Kashar cheeses. Turk. J. Vet. Anim. Sci. 27, 821825.

15. Hayaloglu, A. A. and Kirbag, S. (2007) Microbial quality and presence of molds in Kuflu cheese. Int. J. Food Microbiol. 115, 376-380.

16. Hayaloglu, A. A. (2009) Volatile composition and proteolysis in traditionally produced mature Kashar cheese. Int. J. Food Sci. Tech. 44, 1388-1394.

17. Koca, N. and Metin, M. (2004) Textural, melting and sensory properties of low-fat fresh Kashar cheeses produced by using fat replacers. Int. Dairy J. 14, 365-373.

18. Koyuncu, N. and Uylaser, V. (2009) Determination of benzoic and sorbic acid in Turkish Food using high-performance liquid Chromatography. J. Food Proces. Pres. 33, 361-369.

19. Kucukcetin, A., Sik, B., Cicek, A., and Certel, M. (2004) Determination of sodium benzoate and potassium sorbate in yoghurt and white pickled cheese by HPLC. Milchwissenschaft 59, 420-422.

20. Kucukcetin, A., Sik, B., and Demir, M. (2008) Determination of sodium benzoate, potassium sorbate, nitrate and nitrite in some commercial dairy products. GIDI YIL 33, 159-164.

21. Mc Brearty, S., Ross, R. P., Fitzgerald, G. F., Collins, J. K., Wallace, J. M., and Stanaton, C. (2001) Influence of two commercially available bifidobacteria cultures on Cheddar cheese quality. Int. Dairy J. 11, 599-610.

22. Mpountoukas, P., Vantarakis, A., Sivridis, E., and Lialiaris, T. (2008) Cytogenetic study in cultured human lymphocytes treated with three commonly used preservatives. Food Chem. Toxicol. 46, 2390-2393.

23. Oksuztepe, G., Padir, B., Dikici, A., and Ilhak, O. I. (2009). Microbiological and chemical Quality of vacuum packaged Kashar cheese marketed in Elazýg. F. U. Sag. Bil. Vet. Derg. 23, 89-94 (in Turkish).

24. Pylypiw, H. M. and Grether, M. T. (2000) Rapid high-performance liquid chromatography method for the analysis of sodium benzoate and potassium sorbate in foods. J. Chromotogr. A. 883, 299-304.

25. Sieber, R., Bütikofer, U., and Bosset, J. O. (1995) Benzoic acid as a natural compound in cultured dairy products and cheese. Int. Dairy J. 5, 221-246.

26. Tfouni, S. A. V. and Toledo, M. C. F. (2002) Determination of benzoic and sorbic acids in Brazilian food. Food Cont. 13, 117-123.

27. Ture, H., Eroglu, E., Ozen, B., and Soyer, F. (2011) Effect of 
biopolymers containing natamycin against Aspergillus niger and Penicillium roquefortii on fresh kashar cheese. Int. J. Food Sci Technol. 46, 154-160.

28. Var, I., Erginkaya, Z., Guven, M., and Kabak, B. (2006) Effects of antifungal agent and packaging material on microflora of Kashar cheese during storage period. Food Cont. 17, 132-136.
29. WHO. (1996) Toxicological evaluation of certain food additives. WHO Food Additives Series No. 37.

30. WHO. (1974) Toxicological evaluation of certain food additives with a review of general principles and of specifications (17th Report of the Expert Committee). WHO Technical Report Series No. 539.

(Received 2013.5.20/Revised 2013.7.17/Accepted 2013.8.13) 